\title{
Repeated disinfectant use in broiler houses and pig nursery units does not affect disinfectant and antibiotic susceptibility in Escherichia coli field isolates
}

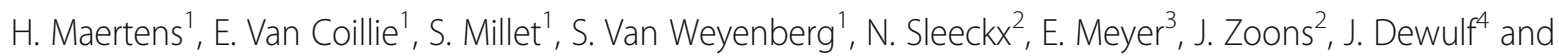
K. De Reu ${ }^{1 *}$ iD

\begin{abstract}
Background: Disinfectants are frequently used in animal production to reduce or eliminate the load of infectious agents and parasites in buildings and equipment associated with the housing or transportation of animals. There are growing concerns that the use of disinfectants would select for resistance to antibiotics and disinfectants. The aim of this study was to determine the effect of repeated use of different disinfectants on the disinfectant and antibiotic susceptibility under practical conditions in a broiler and pig pilot farm. Therefore, the susceptibility of Escherichia coli (E. coli) to 14 antibiotics and 4 disinfectants was monitored over a one-year period.

Results: High (20-50\%) to very high (> 50\%) resistance levels for ampicillin, sulfamethoxazole, trimethoprim and tetracycline were observed in both animal production types. Disinfectant susceptibility did not change over time and did not depend on the used disinfection product. Compared to in-use concentrations of formaldehyde, benzalkoniumchloride and a peracetic acid - hydrogen peroxide formulation, all E. coli strains remained susceptible indicating that the use of disinfectants did not select for disinfectant resistance. Moreover, no association could be found between the use of disinfectants and antibiotic resistance.
\end{abstract}

Conclusions: These findings suggest that repeated use of disinfectants in agricultural environments does not select for antibiotic resistance nor does it reduce disinfectant susceptibility.

Keywords: Disinfectants, Antibiotic resistance, Disinfectant susceptibility, Escherichia coli, Pigs, Poultry

\section{Background}

Biocides are used in animal production to disinfect buildings and equipment associated with the housing or transportation of animals. Their appropriate use preceded by an adequate cleaning is one of the key elements of a good on-farm hygiene management. Cleaning and disinfection $(C \& D)$ are of importance to reduce the

\footnotetext{
* Correspondence: Koen.DeReu@ilvo.vlaanderen.be

${ }^{1}$ Flanders Research Institute for Agriculture, Fisheries and Food (ILVO), Technology and Food Science Unit, Brusselsesteenweg 370, 9090 Melle, Belgium

Full list of author information is available at the end of the article
}

introduction and spread of infectious agents. Cleaning refers to the removal of organic debris as its presence can decrease the antimicrobial activity of the disinfectant. Disinfection reduces or eliminates the load of bacteria and viruses [1], yet bacteria may still be present after C\&D of animal houses [2]. This has led to the hypothesis that bacteria can become resistant to the used disinfectants. In recent years, studies have therefore focused on the disinfectant susceptibility of field bacterial isolates, but the methodologies used to evaluate the susceptibility data lead to heterogeneous results. Evaluation

C C The Author(s). 2020 Open Access This article is licensed under a Creative Commons Attribution 4.0 International License, which permits use, sharing, adaptation, distribution and reproduction in any medium or format, as long as you give appropriate credit to the original author(s) and the source, provide a link to the Creative Commons licence, and indicate if changes were made. The images or other third party material in this article are included in the article's Creative Commons licence, unless indicated otherwise in a credit line to the material. If material is not included in the article's Creative Commons licence and your intended use is not permitted by statutory regulation or exceeds the permitted use, you will need to obtain permission directly from the copyright holder. To view a copy of this licence, visit http://creativecommons.org/licenses/by/4.0/. The Creative Commons Public Domain Dedication waiver (http://creativecommons.org/publicdomain/zero/1.0/) applies to the data made available in this article, unless otherwise stated in a credit line to the data. 
of the frequency distribution of the minimal inhibitory concentration (MIC) and/or minimal bactericidal concentration $(\mathrm{MBC})$ is a first method to investigate resistance. When a homogenous distribution is shown, there is no indication for a reduced susceptibility [3, 4]. Secondly, the lethality of in-use disinfectant concentrations is evaluated via $\mathrm{MBC}$ determinations. Both susceptible and less susceptible field isolates to in-use concentrations have been reported [5]. Thirdly, $\mathrm{MIC}_{90}$ values calculated as the disinfectant concentration that inhibits $90 \%$ of the field isolates are compared with MIC values of a control strain. Reports have shown both similar and reduced susceptibilities [6]. Lastly, concentration criteria are used to categorize isolates as either susceptible, lowlevel resistant, or resistant according to their MIC. For example, a low-level resistance prevalence to benzalkoniumchloride has been found [7].

Furthermore, contradictory results have been found regarding the possible association between the reduced susceptibility to disinfectants and antibiotic resistance in field bacteria [8-11]. Moreover, few studies were performed on the use of disinfectants and the relation to antimicrobial resistance under practical conditions [12].

In exposure experiments under laboratory conditions, it has been shown that stepwise repeated exposure of susceptible bacteria to subinhibitory concentrations of disinfectants may lead to decreased susceptibility to various antimicrobial agents [13-17]. However, many of these investigations do not relate such findings to practical conditions and the laboratory results are not necessarily relevant to agricultural environments. Moreover, few studies investigated changes in antimicrobial susceptibility over time in a practical setting [18]. Therefore, this longitudinal study was carried out to investigate the effect of repeated disinfectant use on antimicrobial susceptibility of Escherichia coli (E. coli), isolated after C\&D in broiler houses and pig nursery units. A broiler is any chicken that is bred and raised specifically for meat production.

\section{Results}

\section{Detection of Escherichia coli}

In the broiler house, positive swabs were detected after disinfection with Virocid, CID20 and D50 in 9.7, 8.6 and $20.1 \%$ of the locations, respectively. In the pig nursery unit, positive swabs were detected in 47.7, 22.9 and $36.8 \%$ of the locations, respectively.

\section{Disinfectant susceptibility}

\section{Disinfectant use and susceptibility}

The $E$. coli isolates ( $n=67$ from the broiler houses, $n=72$ from the pig nursery units), obtained after disinfection were tested for their susceptibility to benzalkoniumchloride, glutaraldehyde, formaldehyde and D50. Disinfectant susceptibility results were homogeneously (normally) distributed within a very small concentration range for all disinfectants tested (Fig. 1a and b). No remarkable differences in MICs were found between the $E$. coli isolates, either with the various disinfectants or between both animal production types.

\section{Disinfectant susceptibility evolution}

No change in susceptibility to benzalkoniumchloride, glutaraldehyde, formaldehyde and $\mathrm{D} 50^{\circ}$ could be observed over time (Fig. 2a and b). Furthermore, as all $E$. coli isolates showed a similar susceptibility to the active components benzalkoniumchloride, glutaraldehyde, formaldehyde and $\mathrm{D} 50^{\circ}$, no indications for disinfectant resistance were found.

\section{Antibiotic resistance}

The 67 E. coli isolates from broiler houses and the 183 isolates from pig nursery units were exposed to a panel of 14 antibiotics to evaluate antibiotic susceptibility (Fig. 3). Occurrence of antibiotic resistance in the broiler houses was very high for ampicillin (69\%), sulfamethoxazole (64\%) and trimethoprim (61\%). A high and moderate antibiotic resistance was found for tetracycline (28\%), ciprofloxacin (19\%) and nalidixic acid (16\%). Resistance toward chloramphenicol was low (4\%). No resistance was found to the other tested antibiotics.

For $E$. coli isolates from pig nursery units, high levels of antibiotic resistance to tetracycline $(45 \%)$, ampicillin (42\%), trimethoprim (36\%) and sulfamethoxazole (35\%) were found. Antibiotic resistance to gentamicin and chloramphenicol was low. Very low to no resistance was found for the other tested antibiotics.

\section{Disinfectant use and antibiotic resistance}

The antibiotic resistance prevalence of $E$. coli, isolated after each disinfection protocol in the corresponding broiler houses and pig nursery units $\mathrm{A}, \mathrm{B}$ and $\mathrm{C}$ is presented in Fig. 4a and b. Logistic regression analysis showed no significant association between the used disinfectants and the antibiotic resistance of the isolates (Supplementary Table 1).

\section{Antibiotic susceptibility evolution}

An increasing trend in antibiotic resistance to ampicillin, sulfamethoxazole and trimethoprim was found between sampling $\mathrm{t} 1$ and $\mathrm{t} 3$ at the broiler pilot farm (Supplementary Fig. 1a). This increase corresponds to the antibiotic treatment of all broiler chickens with penicillins and sulfamides-trimethoprim within this time period (Supplementary Table 2). Furthermore, a clear increase in resistance was also noticed between $\mathrm{t} 3$ and $\mathrm{t} 5$ for tetracycline, ciprofloxacin and nalidixic acid at the broiler 

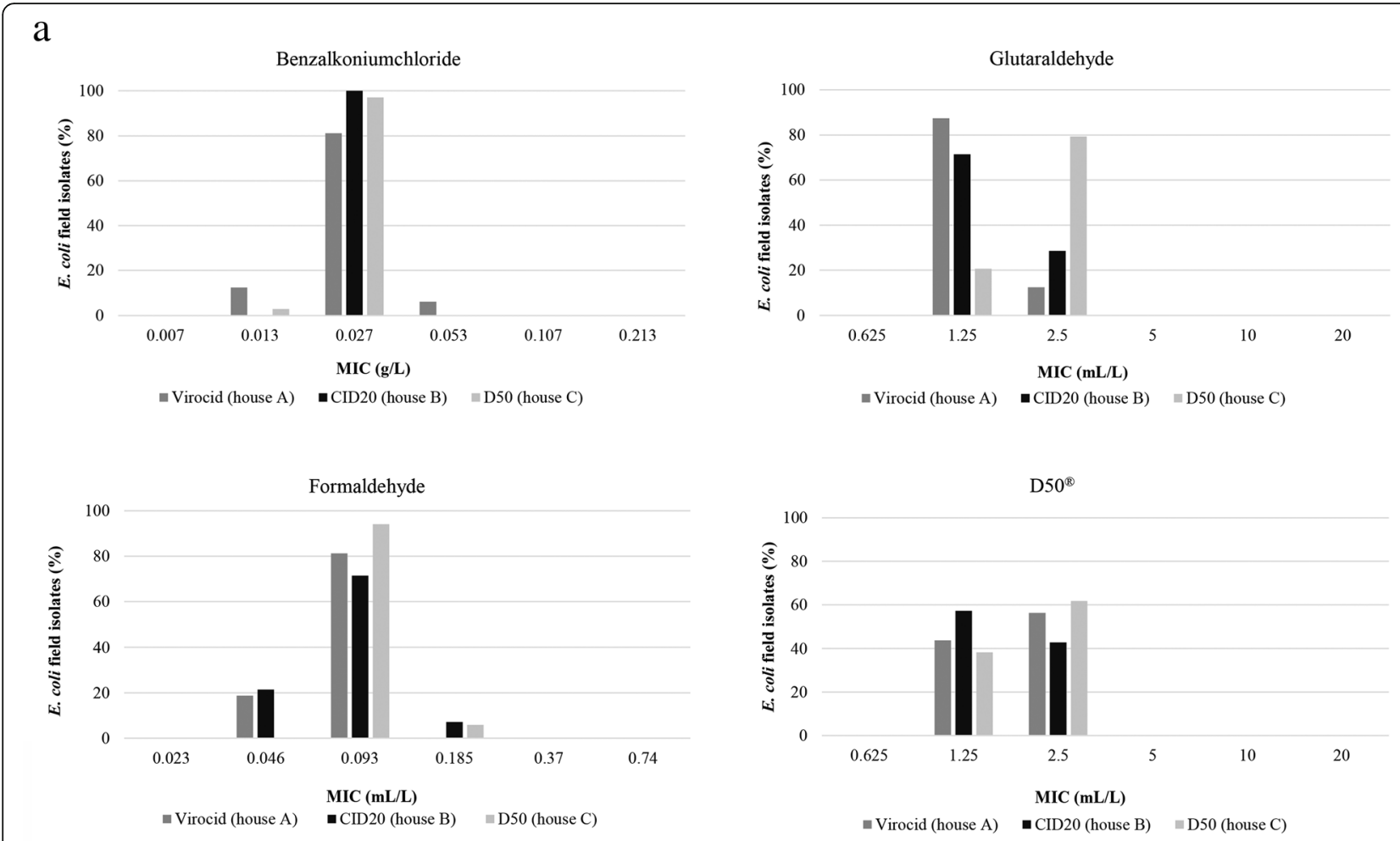

b
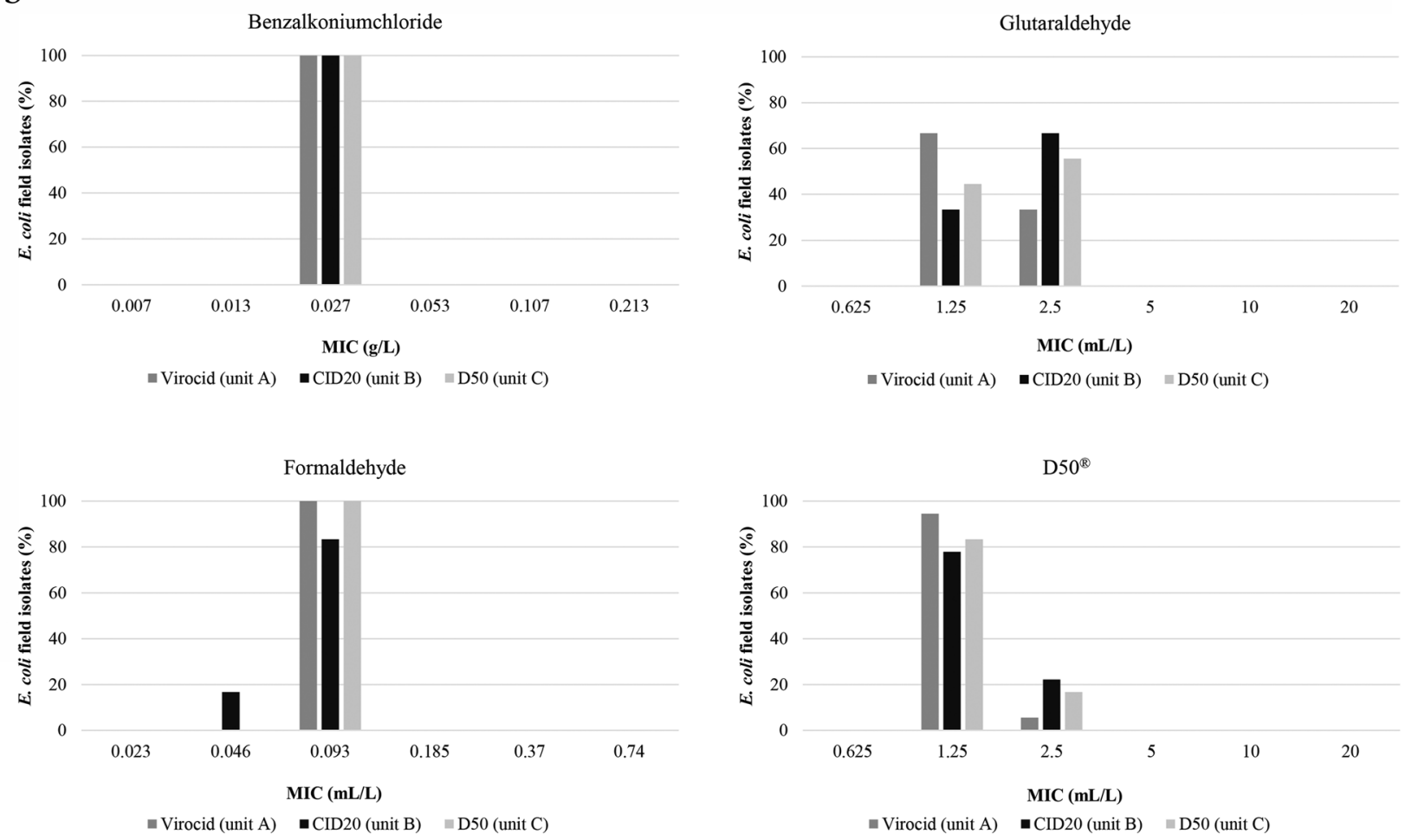

Fig. 1 (See legend on next page.) 
(See figure on previous page.)

Fig. 1 a Percentage of Escherichia coli field isolates with their respective minimum inhibitory concentrations (MICs) displayed on the horizontal axis for benzalkoniumchloride, glutaraldehyde, formaldehyde and D50\%, isolated after the disinfection protocols with Virocid ${ }^{\circ}$ ( $n=16$ ), CID20 $(n=$

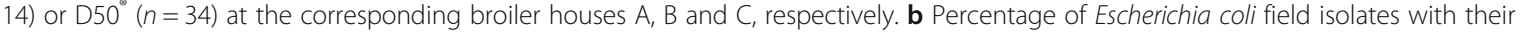
respective minimum inhibitory concentrations (MICs) displayed on the horizontal axis for benzalkoniumchloride, glutaraldehyde, formaldehyde and $\mathrm{D} 50^{\circ}$, isolated after the disinfection (t1, t3 and t5) with Virocid ${ }^{\circ}(n=18), \mathrm{CID}^{\circ}$ ( $\left.n=18\right)$ or D50 $(n=18)$ at the corresponding pig nursery units $A, B$ and $C$, respectively

farm. In this particular period of time the hatchery origin of the one-day old broiler chickens changed.

For the E. coli field isolates obtained at the pig pilot farm, no trend in antibiotic resistance was observed during the study (Supplementary Fig. 1b).

\section{Discussion}

To our knowledge, this is the first longitudinal field study on the effect of repeated use of disinfectants on the antimicrobial susceptibility of $E$. coli field isolates in agricultural environments.

\section{Disinfectant use and susceptibility}

In the current study no evidence was found of reduced susceptibility to the tested active components following disinfection with three different disinfectants at either the broiler houses or the pig nursery units. The MIC values for the disinfectant components were homogenously distributed within a very small concentration range without a bimodal distribution. Furthermore, MIC values of the $E$. coli field isolates for the disinfectant components were similar to those recently reported by our research group [19]. The obtained MIC values of two active components i.e. benzalkoniumchloride and formaldehyde were compared to the in-use concentrations in two evaluated veterinary disinfection products i.e. Virocid and CID20. These MIC values were lower than the recommended concentrations of benzalkoniumchloride and formaldehyde in veterinary disinfection products applied by foaming. This difference indicates that the prescribed commercial product concentrations are sufficiently high to reduce the bacterial load with at least $5 \log$ CFU. In contrast, when comparing the obtained MIC value of the third active component i.e. glutaraldehyde to the in-use concentration of this active component in two of the evaluated veterinary disinfection products i.e. Virocid and CID20, the former MIC value was much higher than the recommended in-use concentration in veterinary disinfection products applied by foaming. However, in practice, aldehyde-based disinfectants are formulated in combination with quaternary ammonium compounds (QACs) such as in Virocid and CID20 to achieve a synergistic effect $[20,21]$. Susceptibility results for the ready-to-use disinfectant $\mathrm{D} 50^{\circ}$, being a peracetic acid and hydrogen peroxide formulation, showed MIC values equal to or below the recommended concentration.

\section{Disinfectant susceptibility evolution}

Reported in vitro disinfectant susceptibility data for bacteria are diverging. Several in vitro studies have shown a reduced susceptibility to disinfectants after repeated exposure of bacteria to subinhibitory concentrations of QACs [15, 22] or even a commercial disinfectant [23]. However, other in vitro studies state the opposite: in the studies of Karatzas et al. (2007) and Webber et al. (2015), with commercially available disinfectants instead of active components, none of the adapted strains demonstrated an increased tolerance after exposure to the commercial disinfectants $[13,16]$. In the current in vivo study, repeated use of the same disinfectant during 5 production cycles did not show changes in disinfectant susceptibility over the (short) monitored time period to either the single active components benzalkoniumchloride, formaldehyde, glutaraldehyde or to the combined formulation D50. Nevertheless, it should be borne in mind that resistance development requires time. The study was carried out on a short term and therefore some caution is warranted in interpreting the results.

It can be hypothesized that the reason for surviving strains after $C \& D$ is not resistance to the disinfectant, but could be (i) an inadequate $C \& D$ at critical locations in the animal production unit which are difficult to C\&D, and/or (ii) residual organic matter, and/or (iii) other factors influencing the efficacy of disinfectants (e.g. disinfectant dilution by remaining rinsing water, environmental temperature). Corroborating this hypothesis, we previously reported that the disinfection of farm buildings and equipment does not lead to sterile surfaces and environments [24].

\section{Disinfectant use and antibiotic resistance}

In the current in vivo study no evidence of reduced susceptibility to the tested antibiotics could be found following repeated disinfection with different disinfectants at the broiler houses and pig nursery units. This is again in contrast to several in vitro studies where a reduced susceptibility to antibiotics after repeated exposure of bacteria to subinhibitory concentrations of an active component $[15,22]$ or even of commercial disinfectants $[13,16,23]$ was shown. The question is how to interpret 


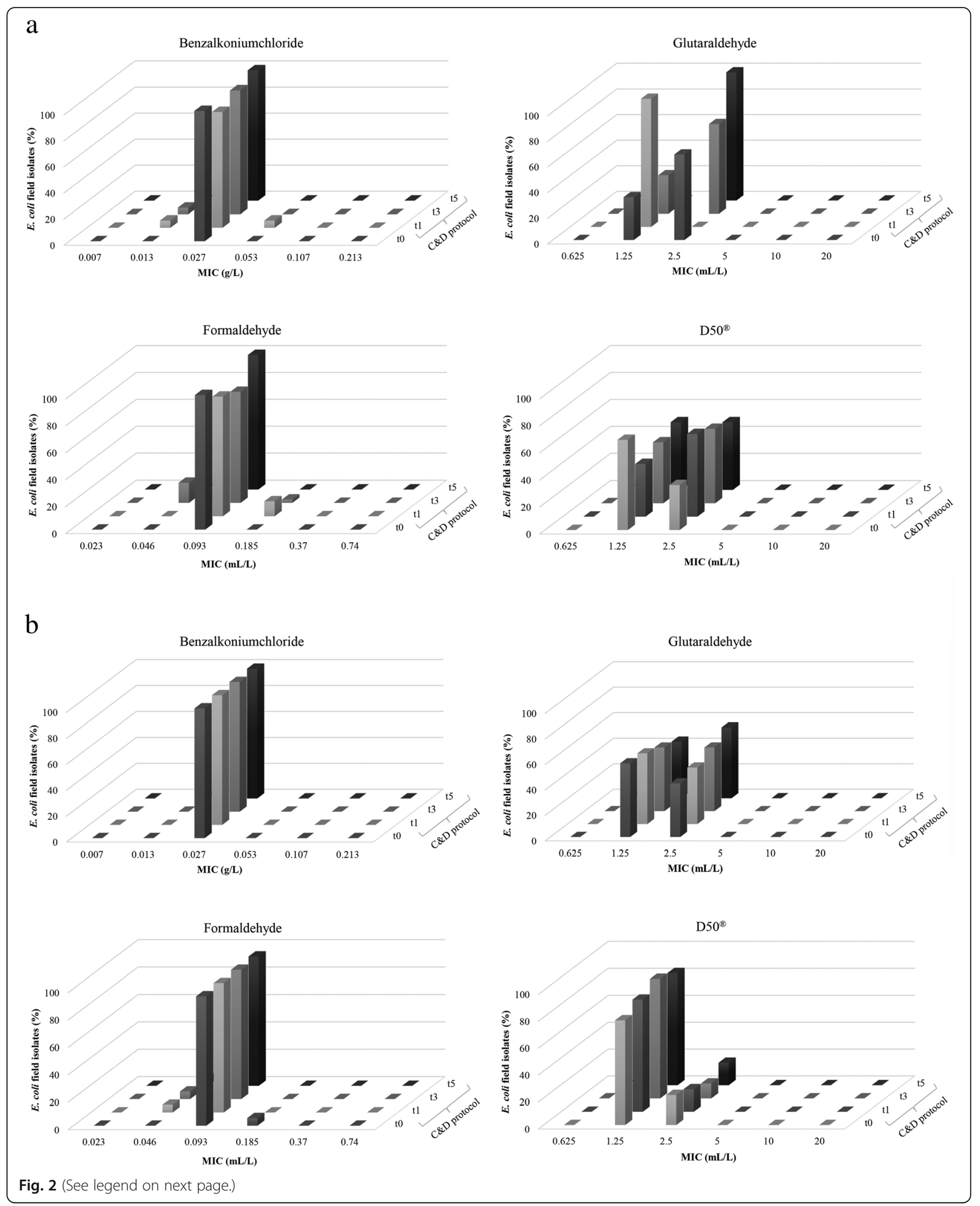


(See figure on previous page.)

Fig. 2 a Evolution in minimum inhibitory concentrations (MICs) of Escherichia coli field isolates for benzalkoniumchloride, glutaraldehyde, formaldehyde and D50, expressed as percentages. Samples were taken after cleaning and disinfection (C\&D) over a period of 6 production cycles: t0 (zero measurement, $n=3$ ), t1 (after production cycle 1, $n=18$ ), t3 (after production cycle 3,n=40) and t5 (after production cycle 5, $n=$ 6) at the pilot broiler farm. Monitoring of C\&D took place from production cycle 1. b Evolution in minimum inhibitory concentrations (MICs) of Escherichia coli field isolates for benzalkoniumchloride, glutaraldehyde, formaldehyde and D50', expressed as percentages. Samples were taken after cleaning and disinfection (C\&D) over a period of 6 production cycles: t0 (zero measurement, $n=18$ ), t1 (after production cycle 1, $n=18$ ), t3 (after production cycle $3, n=18$ ) and 5 (after production cycle $5, n=18$ ) at the pilot pig farm. Monitoring of C\&D took place from production cycle 1 onwards

this subset of data. They at least strongly suggest that, although disinfectant use may lead to an increased antibiotic resistance in vitro, it does not induce the development of such resistance in an agricultural environment.

\section{Antibiotic resistance evolution}

Still, changes in antibiotic resistance were noticed even if logistic regression analysis showed that these high resistance levels were not associated with the use of disinfectants. The increasing antibiotic resistance level to ampicillin, sulfamethoxazole and trimethoprim between sampling $\mathrm{t} 1$ and $\mathrm{t} 3$ at the broiler pilot farm corresponds to the antibiotic treatment of all broiler chickens with penicillins and sulfamidestrimethoprim within this time period. Such association has already been described by our group and others $[25,26]$. Furthermore, the most likely explanation for the high levels of antibiotic resistance to tetracycline, ciprofloxacin and nalidixic acid at the broiler farm at $\mathrm{t} 5$ is a change in hatchery origin of the one-day old broiler chickens, and the age of the parent breeding hens between $\mathrm{t} 3$ and $\mathrm{t} 5$. Unfortunately, no information was available on antibiotic treatments applied in the hatcheries. Last but not least, very high resistance levels of > $50 \%$ were found for ampicillin, sulfamethoxazole, trimethoprim, tetracycline, ciprofloxacin and nalidixic acid in the broiler isolates and high resistance levels of $>20 \%$ to ampicillin, sulfamethoxazole, trimethoprim and tetracycline in the pig isolates. Compared to the Belgian report by CODACERVA (2017) on E. coli in 2016 [27], a lower resistance prevalence was found for both animal production types in our longitudinal study, except for trimethoprim in the broiler pilot farm. However, it should be noted that a limitation of the current study is that it only comprises results of one experimental broiler and one pig farm, which is likely not representative for the average Belgian broiler and pig farm.

\section{Conclusion}

In conclusion, even if some in vitro studies previously reported a decreased antibiotic and/or disinfectant susceptibility after repeated exposure to disinfectants, we could not confirm this observation in our longitudinal field study. Indeed, the repeated use of disinfectants in recommended concentrations in vivo did not influence disinfectant susceptibility of $E$. coli isolated from broiler and pig units. Furthermore, the observed disinfectant susceptibility was also product-independent. Finally, no association was found between the use of disinfectants

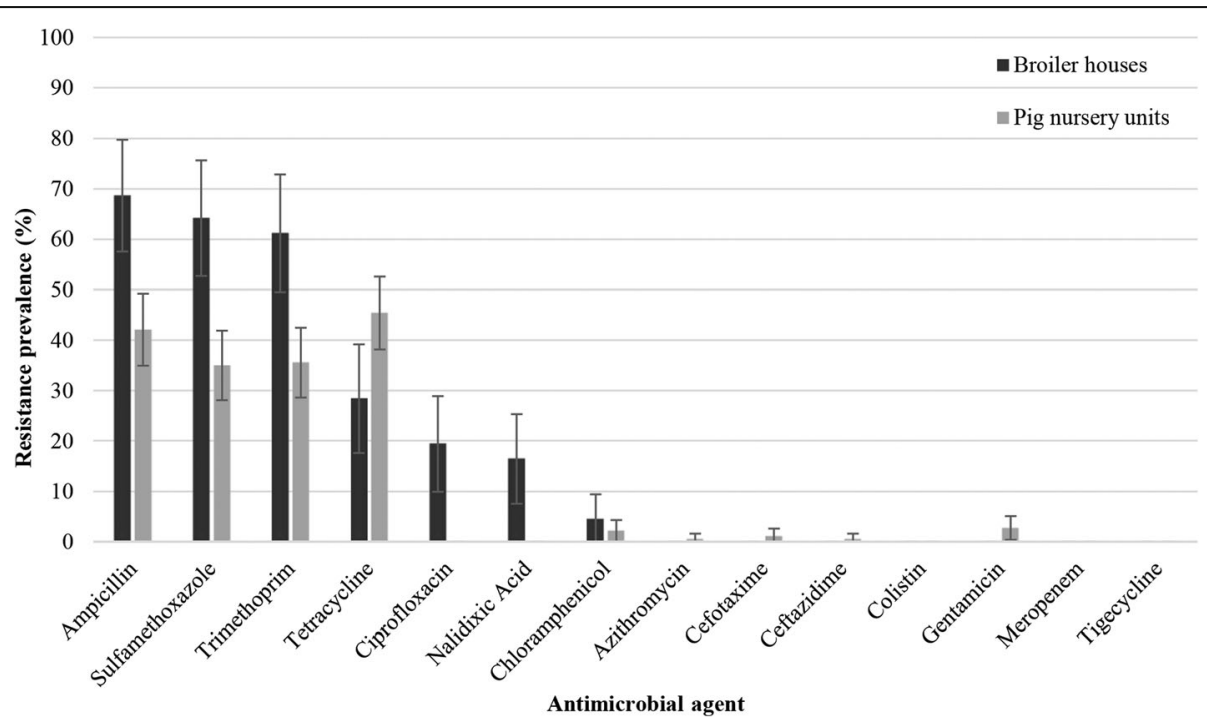

Fig. 3 Prevalence of antibiotic resistance in 67 and 183 Escherichia coli isolated at the 4 sampling moments (t0: zero measurement, t1: after production cycle 1, t3: after production cycle 3 and t5: after production cycle 5) after cleaning and disinfection over 6 production cycles in 3 broiler houses and 3 pig nursery units, respectively (expressed as percentage). Error bars represent the standard errors 


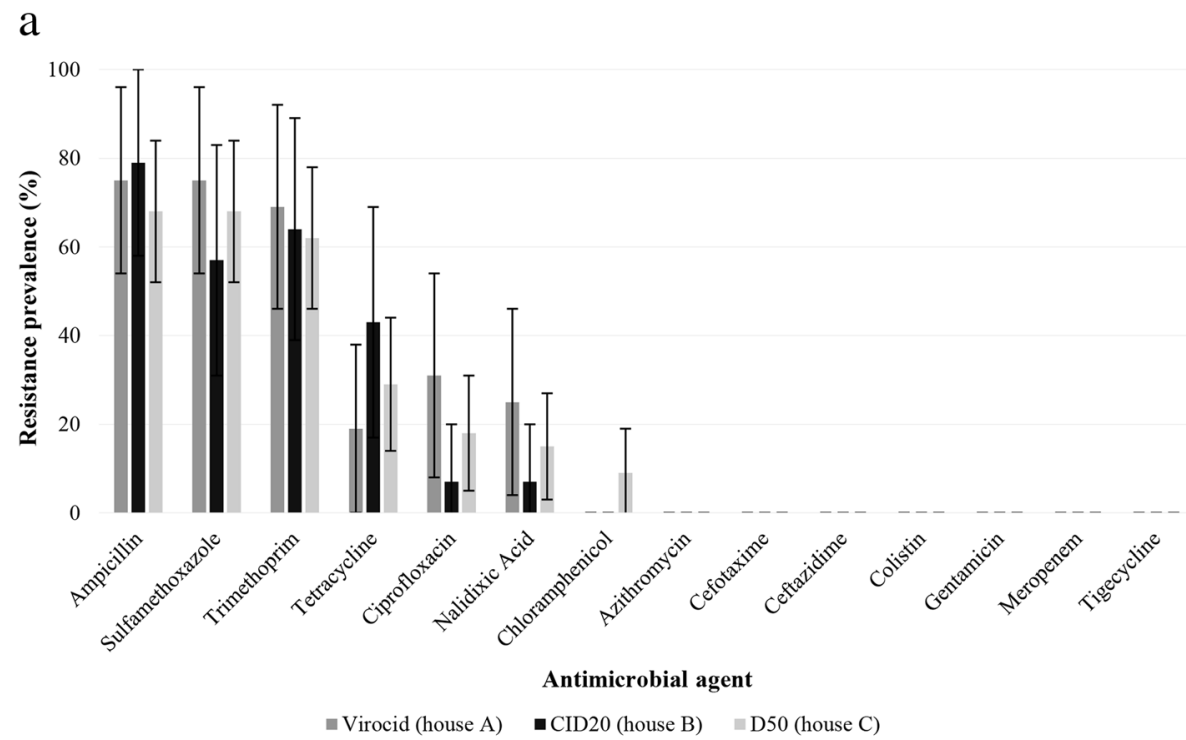

b

100

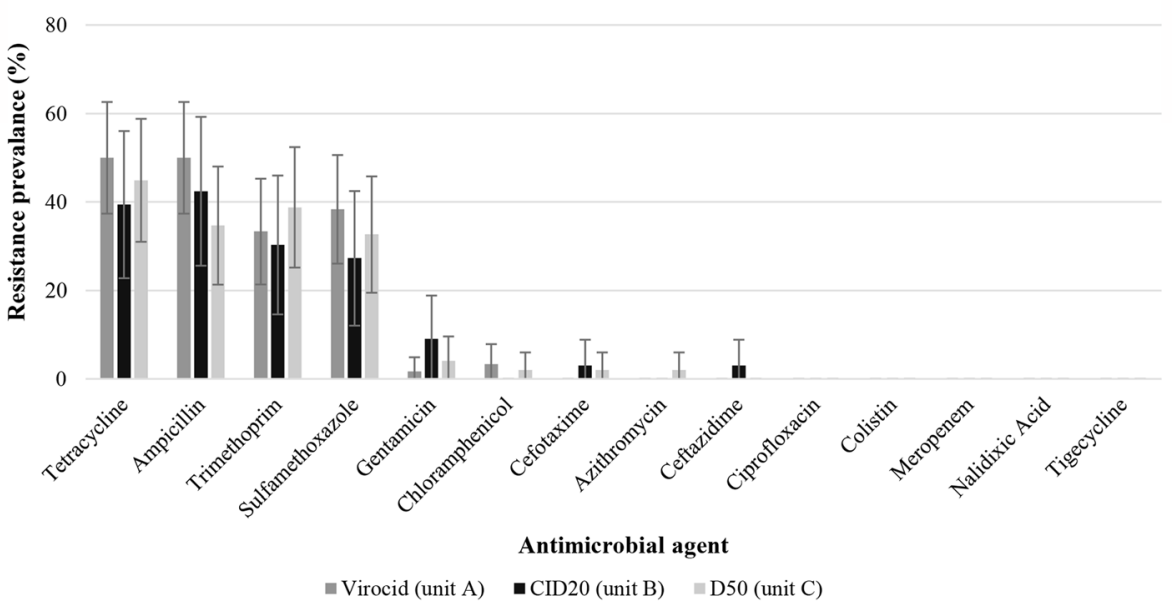

Fig. 4 a Prevalence of antibiotic resistance in Escherichia coli isolated after the disinfection protocols with Virocid $(n=16), \mathrm{CID}^{\circ} 0^{\circ}(n=14)$ or D50 $(n=34)$ at the corresponding broiler houses, sampled 3 times ( 1 : after production cycle 1, t3: after production cycle 3 and t5: after production cycle 5) (expressed as percentage). Error bars represent the standard errors. b Prevalence of antibiotic resistance in Escherichia coli isolated after the disinfection protocols with Virocid ${ }^{\circ}(n=60), \mathrm{CID}^{\circ} 0^{\circ}(n=33)$ or D50 $(n=50)$ at the corresponding pig nursery units, sampled 3 times (expressed as percentage). Error bars represent the standard errors

in both agricultural environments and the antibiotic resistance of the broiler and pig farm E. coli strains.

\section{Methods}

\section{Management of C\&D in the broiler houses and pig nursery units}

The longitudinal study was carried out in three identical broiler houses at a pilot farm for broiler chickens $( \pm$ 6000 broilers/house) of the Experimental Poultry Centre (EPC, Geel, Belgium) and in three identical pig nursery units ( 8 pens with 6 piglets per pen) at the experimental pig farm of the Flanders Research Institute for Agriculture, Fisheries and Food (ILVO) for 6 successive production cycles between May 2017 and May 2018. After the first production cycle, conventional C\&D was carried out as follows: cleaning of the three broiler houses was applied by high pressure cleaning with a detergent (Kenosan, CID LINES, Ieper, Belgium) and disinfection was applied by fogging with a quaternary ammonium compound, glutaraldehyde and formaldehyde based disinfectant (CID20, CID LINES). In the pig nursery units high pressure cleaning was performed only with hot 
water $\left( \pm 65^{\circ} \mathrm{C}\right)$ followed by a disinfection with quaternary ammonium compounds and glutaraldehyde (MS Megades', MS Schippers, Bladel, The Netherlands) via foaming. Subsequently, different C\&D protocols were applied during 5 successive production cycles. Cleaning of all broiler houses and pig nursery units was carried out by high pressure cleaning with Kenosan and disinfection was applied by fogging at the broiler houses and by foaming at the pig nursery units. Selection of three commercially available disinfectants was based on frequently used combinations of active components in poultry houses and pig nursery units, described by Maertens et al. $(2018,2019)[19,28]$. Each disinfection product was applied during 5 successive production cycles in the same broiler house or pig nursery unit. The applied disinfection products consisted of (A) quaternary ammonium compounds and glutaraldehyde (QAC-GA; Virocid, CID LINES), (B) quaternary ammonium compounds, glutaraldehyde and formaldehyde (QAC-GA-F; CID20, CID LINES) and (C) peracetic acid and hydrogen peroxide (PA- $\mathrm{H}_{2} \mathrm{O}_{2} ;$ D50, CID LINES). An overview of the used products, methods and product concentrations is given in Table 1.

\section{Quantification of antibiotic use}

The antibiotic use at the sampled pilot farms was recorded via prescriptions and order forms. For each treatment, the product name, the amount of administration and the age (days) and weight $(\mathrm{kg})$ of treated animals were recorded. Quantification of drug use was done as described in Maertens et al. (2019) [19] by determining the treatment incidence (TI) defined as the number of treatment days per 100 days or the percentage of treatment days [29].

\section{Sampling and sampling processing}

Sampling was performed $\pm 24 \mathrm{~h}$ after disinfection at each broiler house or pig nursery unit at the following moments: t0 (zero measurement, after production cycle $0=$ conventional C\&D), t1 (after production cycle 1), t3 (after production cycle 3 ) and $t 5$ (after production cycle 5) (Table 1). Sponge swabs were pre-moistened with 10 $\mathrm{mL}$ Dey Engley Neutralizing Broth (Sigma Aldrich, D3435, St-Louis, USA). Permission to collect samples was obtained from the EPC and the ILVO.

At each broiler house eight locations (floor, floor crack, drain hole, air inlet, drinking cups, pipes, wall and feed pan) were swabbed 8 times, except for the drain holes since only 2 drain holes were present in each broiler house, resulting in 58 samples. As three houses were included in the study, 174 samples were taken per sampling thus obtaining a total of 696 samples after 4 sampling moments.

Table 1 Cleaning and disinfection (C\&D) protocols carried out at the start of the longitudinal study (conventional C\&D) followed by C\&D with 3 C\&D protocols (A, B and C) carried out during 5 successive production cycles in each of the broiler houses or pig nursery units at the pilot farms

\begin{tabular}{|c|c|c|c|c|c|c|c|c|}
\hline \multirow{2}{*}{\multicolumn{3}{|c|}{$\begin{array}{l}\text { Conventional C\&D (sampling after production } \\
\text { cycle 0) }\end{array}$}} & \multicolumn{3}{|c|}{ Broiler house $\left(1050 \mathrm{~m}^{3}\right)$} & \multicolumn{3}{|c|}{ Pig nursery unit } \\
\hline & & & A & B & $\mathrm{C}$ & A & B & $\mathrm{C}$ \\
\hline & Cleaning & Product & \multicolumn{3}{|l|}{ Kenosan } & \multicolumn{3}{|c|}{ No cleaning product } \\
\hline & & Concentration & \multicolumn{6}{|l|}{$1 \%$} \\
\hline & & Method & \multicolumn{6}{|l|}{ foaming } \\
\hline & Disinfection & Product & \multicolumn{3}{|l|}{$\mathrm{CID} 20^{\circ}$} & \multicolumn{3}{|c|}{ MS Megades ${ }^{\circledR}$} \\
\hline & & Concentration & \multicolumn{3}{|c|}{$31 / 61$ water } & \multicolumn{3}{|l|}{$1 \%$} \\
\hline & & Method & \multicolumn{3}{|l|}{ fogging } & \multicolumn{3}{|l|}{ foaming } \\
\hline & & $\begin{array}{l}\text { Active } \\
\text { components }\end{array}$ & \multicolumn{3}{|l|}{ QAC-GA-F } & \multicolumn{3}{|l|}{ QAC-GA } \\
\hline \multirow{9}{*}{$\begin{array}{l}\text { C\&D protocol (sampling after production } \\
\text { cycle } 1,3 \text { and } 5 \text { ) }\end{array}$} & & & \multicolumn{3}{|c|}{ Broiler house } & \multicolumn{3}{|c|}{ Pig nursery unit } \\
\hline & & & A & B & $\mathrm{C}$ & A & B & $\mathrm{C}$ \\
\hline & Cleaning & Product & \multicolumn{3}{|l|}{ Kenosan $^{\circledast}$} & \multicolumn{3}{|l|}{ Kenosan $^{\circledast}$} \\
\hline & & Concentration & \multicolumn{3}{|l|}{$1 \%$} & \multicolumn{3}{|l|}{$1.5 \%$} \\
\hline & & Method & \multicolumn{3}{|l|}{ foaming } & \multicolumn{3}{|l|}{ foaming } \\
\hline & Disinfection & Product & Virocid $^{\circ}$ & $\mathrm{CID} 20^{\circ}$ & $\mathrm{D} 50^{\circ}$ & Virocid $^{\circ}$ & $\mathrm{CID} 20^{\circ}$ & $\mathrm{D} 50^{\circ}$ \\
\hline & & Concentration & $\begin{array}{l}21 / 4 \mid \\
\text { water }\end{array}$ & $\begin{array}{l}4 \mid / 4 I \\
\text { water }\end{array}$ & $\begin{array}{l}4 \mid / 81 \\
\text { water }\end{array}$ & $0.25 \%$ & $0.5 \%$ & $0.5 \%$ \\
\hline & & Method & fogging & fogging & fogging & foaming & foaming & foaming \\
\hline & & $\begin{array}{l}\text { Active } \\
\text { components }^{*}\end{array}$ & QAC-GA & QAC-GA-F & $\mathrm{PA}-\mathrm{H}_{2} \mathrm{O}_{2}$ & QAC-GA & $\begin{array}{l}\text { QAC- } \\
\text { GA-F }\end{array}$ & $\begin{array}{l}\text { PA- } \\
\mathrm{H}_{2} \mathrm{O}_{2}\end{array}$ \\
\hline
\end{tabular}


For each pig nursery unit, each pen was sampled at six different locations (floor, concrete wall, synthetic wall, feeding trough, drinking nipples and pipes) resulting in 48 samples per pig nursery unit, hence 144 samples per sampling moment and a total of 576 swab samples during the entire longitudinal study. Whenever possible, a surface of $625 \mathrm{~cm}^{2}$ was swabbed. Since the surface of the drinking cups and nipples was smaller than $625 \mathrm{~cm} 2$, a total amount of five and two were swabbed at each broiler house and pig nursery unit, respectively. After sampling, swab samples were transported to the lab in a cool box with ice packs.

\section{Detection and isolation of Escherichia coli}

On the same day, each swab sample was enriched with $10 \mathrm{~mL}$ of Buffered Peptone Water (BPW, Oxoid, CM0509, Basingstoke, Hampshire, England), homogenized by a Masticator (IUL instruments, S.A., Barcelona, Spain) and incubated for $24 \mathrm{~h}$ at $37^{\circ} \mathrm{C}$ for the detection of E. coli. After incubation, $10 \mu \mathrm{L}$ of the BPW fraction was plated on Rapid'E. coli 2 agar plates (Bio-Rad, 3564024, Marnes-la-Coquette, France) and incubated at $44^{\circ} \mathrm{C}$ for $24 \mathrm{~h}$. From each positive Rapid'E. coli 2 plate one isolate was purified and stored at $-80^{\circ} \mathrm{C}$ on brain heart infusion (BHI, Oxoid, CM1032) supplemented with $15 \%(\mathrm{v} / \mathrm{v})$ glycerol. In total, 67 and $183 \mathrm{E}$. coli isolates were obtained during the longitudinal study at the broiler pilot farm and the experimental pig farm, respectively.

\section{Disinfectant susceptibility testing Isolate and disinfectant selection}

All 67 isolates from the broiler pilot farm were selected for disinfectant susceptibility testing. For the isolates from the experimental pig farm, a random selection was made of 6 isolates for each sampling and each sampled pig nursery unit, resulting in 72 pig isolates, representing $\pm 40 \%$ of the total amount.

In our previous study [19] no difference was observed for the selected disinfectants between the MIC (minimal inhibitory concentration $=$ minimal concentration that inhibits growth) and MBC (minimal bactericidal concentration $=$ minimal concentration that results in $\sim 5 \log$ CFU reduction). Therefore, in the current study only the MICs were determined. Based on the used disinfectants at the pilot farms, active components present in the disinfectants were selected. These are: alkyldimethylbenzylammoniumchloride (BKC, >95\%, Sigma Aldrich, 12, 060), formaldehyde ( $F, 35 \% \mathrm{v} / \mathrm{v}$ in $\mathrm{H}_{2} \mathrm{O}$, Sigma Aldrich, 252,549), glutaraldehyde (GA, $50 \% \mathrm{w} / \mathrm{v}$ in $\mathrm{H}_{2} \mathrm{O}$, Sigma Aldrich, 3802) and a chemically stable formulation of peroxyacetic acid (PA, $55 \mathrm{~g} / \mathrm{L}$ ) and hydrogen peroxide $\left(\mathrm{H}_{2} \mathrm{O}_{2}, 220 \mathrm{~g} / \mathrm{L}\right)$ (D50, CID LINES, Ieper, Belgium) as hydrogen peroxide is not stable and rapidly degrades into water and oxygen and PA can also decompose to acetic acid and oxygen [30].

\section{Inoculum preparation}

Preparation of the inoculum was based on Maertens et al. (2019) [19].

\section{Minimal inhibitory concentration (MIC)}

Through a broth micro-dilution method based on the method described by Knapp et al. (2015) [31], the MICs of each active component (BKC, F and GA) or given formulation $\left(\mathrm{D} 50^{\circ}\right)$ were determined for the selected isolates. The MIC was defined as the lowest concentration of active components or formulation where no growth was visually observed. A 96-well microtiter plate with Ushaped wells (Novolab, A19652) was filled with $50 \mu \mathrm{L}$ TSB containing twofold dilutions of the active component or formulation. Fifty microliters of the field isolates $\left(1-5 \times 10^{8}\right.$ CFU bacterial $\left./ \mathrm{mL}\right)$ was added to the TSB in the microtiter plate, resulting in a total volume of $100 \mu \mathrm{L}$. Final concentration ranges were as follows: 0.007-0.213 g/L BKC, $0.023-0.740 \mathrm{~mL} / \mathrm{L} \mathrm{F,} \mathrm{0.625-20}$ $\mathrm{mL} / \mathrm{L}$ GA and $0.625-20 \mathrm{~mL} / \mathrm{L}$ D50 . As a positive control, $50 \mu \mathrm{L}$ of each bacterial suspension was added to $50 \mu \mathrm{L}$ TSB without disinfectant. To check for possible contamination, wells without bacterial suspension and disinfectant served as blank. After inoculation, plates were incubated for $24 \mathrm{~h}$ in a shaking incubator (100 $\mathrm{rpm})$ at $37^{\circ} \mathrm{C}$. After incubation, the MICs were read. In every experiment the E. coli ATCC strains 10536 and 25922 were used as controls.

\section{Antibiotic susceptibility testing}

Antibiotic susceptibility testing was performed on all $E$. coli broiler pilot farm isolates $(n=67)$ and experimental pig farm isolates $(n=183)$, using a microdilution method (Sensititre) based on Maertens et al. (2019) [19].

\section{Data analysis}

For both animal categories, antibiotic resistance data of the E. coli isolated after disinfection were each grouped for every sampling moment and disinfectant. A binary logistic regression model was fitted to the data with the antibiotic resistance profile at herd level (resistant/susceptible) as the dichotomous dependent variable and with the applied disinfectants, moment of sampling ( $t 1$, t3 and t5) and antibiotic use (TI100) as independent variables. $P$-values $\leq 0.05$ were considered to be significant. All statistical analyses were performed using the Statistical Package for the Social Sciences (SPSS Statistics 25.0, IBM Corporation, Armonk, NY). Data of the conventional $C \& D$ (sampling at $t 0$ ) were not included in the analysis. 


\section{Supplementary information}

Supplementary information accompanies this paper at https://doi.org/10. 1186/s12917-020-02342-2.

Additional file 1: Supplementary Table 1. Statistical output of the logistic regression analysis.

Additional file 2: Supplementary Fig. 1a and b. Prevalence of antibiotic resistance in Escherichia coli isolated from the broiler houses and the pig nursery units.

Additional file 3: Supplementary Table 2. Antibiotic use at the broiler pilot farm.

\section{Abbreviations}

BKC: Benzalkoniumchloride; BPW: Buffered Peptone Water; C\&D: Cleaning and disinfection; CFU: Colony forming units; DE broth: Dey Engley Neutralizing Broth; E. coli: Escherichia coli; ECOFF: Epidemiological cut-off; F: Formaldehyde; $\mathrm{GA}$ : Glutaraldehyde; $\mathrm{H}_{2} \mathrm{O}_{2}$ : Hydrogen peroxide; ILVO: Flanders Research Institute for Agriculture, Fisheries and Food; MBC: Minimum Bactericidal Concentration; MHB: Mueller-Hinton broth; MIC: Minimum Inhibitory Concentration; PA: Peracetic acid; PCA: Plate Count Agar; QAC: Quaternary ammonium compound; TSB: Trypton Soya Broth

\section{Acknowledgements}

The practical assistance of Tatjana De Maeyer, Eline Dumoleijn and Kristof Dierkens was greatly appreciated. We are grateful to Ellen Vervaet for her technical support.

\section{Authors' contributions}

HM was involved in the sample collection, laboratory analyses, analysis and interpretation of the data and drafting the manuscript. KD, EVC, JD, SM and JZ coordinated the study. SWW and JD evaluated the statistical analyses. HM, $K D, E V C, J D, E M, S M$ and NS contributed to development and writing of the paper. All authors read and approved the final manuscript.

\section{Funding}

This research is funded by the Belgian Federal Public Service for Health, Food Chain Safety and Environment [RT14/2 Biocamrisk]. The funding body did not participate in study design, data collection, analysis and interpretation or writing of the manuscript.

\section{Availability of data and materials}

The datasets used and analysed during the current study are available from the corresponding author on reasonable request.

\section{Ethics approval and consent to participate}

Permission from the Experimental Poultry Center (EPC) and Animal Sciences Unit of the Flanders Research Institute for Agriculture, Fisheries and Food (ILVO) was obtained.

\section{Consent for publication}

Not applicable.

\section{Competing interests}

The authors declare that they have no competing interests.

\section{Author details}

'Flanders Research Institute for Agriculture, Fisheries and Food (ILVO), Technology and Food Science Unit, Brusselsesteenweg 370, 9090 Melle, Belgium. ${ }^{2}$ Experimental Poultry Center (EPC), Poiel 77, 2440 Geel, Belgium. ${ }^{3}$ Veterinary Biochemistry Unit, Department of Pharmacology, Toxicology and Biochemistry, Faculty of Veterinary Medicine, Ghent University, Salisburylaan 133, 9820 Merelbeke, Belgium. ${ }^{4}$ Veterinary Epidemiology Unit, Department of Reproduction, Obstetrics and Herd Health, Faculty of Veterinary Medicine, Ghent University, Salisburylaan 133, 9820 Merelbeke, Belgium.
Received: 2 October 2019 Accepted: 22 April 2020

Published online: 18 May 2020

\section{References}

1. Van Immerseel F, Luyckx K, De Reu K, Dewulf J. Cleaning and disinfection. In: Dewulf J, Van Immerseel F, editors. Biosecurity in animal production and Veterinary medicine. First edit. Acco; 2018.

2. Luyckx K, Dewulf J, Van Weyenberg S, Herman L, Zoons J, Vervaet E, et al. Comparison of sampling procedures and microbiological and nonmicrobiological parameters to evaluate cleaning and disinfection in broiler houses. Poult Sci. 2015:94:740-9.

3. Oosterik LH, Peeters L, Mutuku I, Goddeeris BM, Butaye P. Susceptibility of avian pathogenic Escherichia coli from laying hens in Belgium to antibiotics and disinfectants and Integron prevalence. Avian Dis. 2014;58(2):271-8.

4. Seier-Petersen MA, Nielsen LN, Ingmer H, Aarestrup FM, Agers $\varnothing$ Y. Biocide susceptibility of Staphylococcus aureus CC398 and CC30 isolates from pigs and identification of the biocide resistance genes, gacG and gacC. Microb Drug Resist. 2015;21(5):527-36.

5. Luyckx K, Van Coillie E, Dewulf J, Van Weyenberg S, Herman L, Zoons J, et al. Identification and biocide susceptibility of dominant bacteria after cleaning and disinfection of broiler houses. Poult Sci. 2017;96:938-49.

6. Long M, Lai H, Deng W, Zhou K, Li B, Liu S, et al. Disinfectant susceptibility of different Salmonella serotypes isolated from chicken and egg production chains. J Appl Microbiol. 2016:121:672-81.

7. Beier RC, Franz E, Bono JL, Mandrell RE, Fratamico PM, Callaway TR, et al. Disinfectant and antimicrobial susceptibility profiles of the big six non-0157 Shiga toxin-producing Escherichia coli strains from food animals and humans. J Food Prot. 2016;79(8):1355-70.

8. Fernández Márquez ML, Grande Burgos MJ, Pérez Pulido R, Gálvez A, Lucas $L R$. Biocide tolerance and antibiotic resistance in Salmonella isolates from hen eggshells. Foodborne Pathog Dis. 2017;14(2):89-95.

9. Gantzhorn MR, Pedersen K, Olsen JE, Thomsen LE. Biocide and antibiotic susceptibility of Salmonella isolates obtained before and after cleaning at six Danish pig slaughterhouses. Int J Food Microbiol. 2014;181:53-9.

10. Herruzo I, Herruzo R, Vizcaino M. Is there a correlation between antibiotic resistance and decreased susceptibility to biocides in different genus of bacterial genera? J Antibiot Res. 2015;1(1):1-7.

11. Wieland N, Boss J, Lettmann S, Fritz B, Schwaiger K, Bauer J, et al. Susceptibility to disinfectants in antimicrobial-resistant and -susceptible isolates of Escherichia coli, Enterococcus faecalis and Enterococcus faecium from poultry-ESBL/ AmpC-phenotype of E. coli is not associated with resistance to a quaternary ammonium compound, DDAC. J Appl Microbiol. 2017:122:1508-17.

12. Gradel KO, Randall L, Sayers AR, Davies RH. Possible associations between Salmonella persistence in poultry houses and resistance to commonly used disinfectants and a putative role of mar. Vet Microbiol. 2005;107:127-38.

13. Webber MA, Whitehead RN, Mount M, Loman NJ, Pallen MJ, Piddock LJV. Parallel evolutionary pathways to antibiotic resistance selected by biocide exposure. J Antimicrob Chemother. 2015;70:2241-8.

14. Alonso-Hernando A, Capita R, Prieto M, Alonso-Calleja C. Comparison of antibiotic resistance patterns in Listeria monocytogenes and Salmonella enterica strains pre-exposed and exposed to poultry decontaminants. Food Control. 2009;20(12):1108-11.

15. Soumet $C$, Méheust $D$, Pissavin $C$, Le Grandois P, Frémaux $B$, Freurer $C$ et al. Reduced susceptibilities to biocides and resistance to antibiotics in foodassociated bacteria following exposure to quaternary ammonium compounds. J Appl Microbiol. 2016;121:1275-81.

16. Karatzas KAG, Webber MA, Jorgensen F, Woodward MJ, Piddock LJV, Humphrey TJ. Prolonged treatment of Salmonella enterica serovar Typhimurium with commercial disinfectants selects for multiple antibiotic resistance, increased efflux and reduced invasiveness. J Antimicrob Chemother. 2007;60(5):947-55.

17. Randall LP, Cooles SW, Piddock LJV, Woodward MJ. Effect of triclosan or a phenolic farm disinfectant on the selection of antibiotic-resistant Salmonella enterica. J Antimicrob Chemother. 2004:54:621-7.

18. Russell AD. Biocide use and antibiotic resistance: the relevance of laboratory findings to clinical and environmental situations. Lancet Infect Dis. 2003; 3(12):794-803.

19. Maertens H, De Reu K, Meyer E, Van Coillie E, Dewulf J. Limited association between disinfectant use and either antibiotic or disinfectant susceptibility 
of Escherichia coli in both poultry and pig husbandry. BMC Vet Res. 2019; 15(310): $1-12$

20. Jeffrey DJ. Chemicals used as disinfectants: active ingredients and enhancing additives. Rev Sci Tech. 1995;14(1):57-74.

21. Gorman S, Scott E. Microbiological Aspects of Pharmaceutical Processing: Chemical disinfectants, antiseptics and preservatives. In: Denyer SP, Hodges NA, Gorman SP, editors. Hugo and Russell's Pharmaceutical Microbiology. 7th ed. Massachusetts: Blackwell Science; 2004. p. 285-305.

22. Braoudaki M, Hilton AC. Adaptive resistance to biocides in Salmonella enterica and Escherichia coli 0157 and cross-resistance to antimicrobial agents. J Clin Microbiol. 2004:42(1):73-8.

23. Nhung NT, Thuy CT, Trung NV, Campbell J, Baker S, Thwaites G, et al. Induction of antimicrobial resistance in Escherichia coli and non-Typhoidal Salmonella strains after adaptation to disinfectant commonly used on farms in Vietnam. Antibiotics. 2015:4:480-94.

24. Luyckx KY, Van Weyenberg S, Dewulf J, Herman L, Zoons J, Vervaet E, et al. On-farm comparisons of different cleaning protocols in broiler houses. Poult Sci. 2015;94:1986-93.

25. Chantziaras I, Boyen F, Callens B, Dewulf J. Correlation between veterinary antimicrobial use and antimicrobial resistance in food-producing animals: a report on seven countries. J Antimicrob Chemother. 2014;69:827-34.

26. Callens B, Cargnel M, Sarrazin S, Dewulf J, Hoet B, Vermeersch K, et al. Associations between a decreased veterinary antimicrobial use and resistance in commensal Escherichia coli from Belgian livestock species (2011-2015). Prev Vet Med. 2018;157:50-8.

27. CODA-CERVA. Antimicrobial Resistance in commensal Escherichia coli from livestock in Belgium. In: Trend Analysis 2011-2016; 2017.

28. Maertens H, De Reu K, Van Weyenberg S, Van Coillie E, Meyer E, Van Meirhaeghe $\mathrm{H}$, et al. Evaluation of the hygienogram scores and related data obtained after cleaning and disinfection of poultry houses in Flanders during the period 2007 to 2014. Poult Sci. 2018;97:620-7.

29. Timmerman T, Dewulf J, Catry B, Feyen B, Opsomer G, de Kruif A, et al. Quantification and evaluation of antimicrobial drug use in group treatments for fattening pigs in Belgium. Prev Vet Med. 2006;74(4):251-63.

30. McDonnell G, Russell AD. Antiseptics and disinfectants: activity, Action and Resistance. Clin Microbiol Rev. 1999;12(1):147-79.

31. Knapp L, Amézquita A, McClure P. Stewart S, Maillard JY. Development of a protocol for predicting bacterial resistance to microbicides. Appl Environ Microbiol. 2015;81(8):2652-9.

\section{Publisher's Note}

Springer Nature remains neutral with regard to jurisdictional claims in published maps and institutional affiliations.

Ready to submit your research? Choose BMC and benefit from:

- fast, convenient online submission

- thorough peer review by experienced researchers in your field

- rapid publication on acceptance

- support for research data, including large and complex data types

- gold Open Access which fosters wider collaboration and increased citations

- maximum visibility for your research: over $100 \mathrm{M}$ website views per year

At $\mathrm{BMC}$, research is always in progress.

Learn more biomedcentral.com/submissions 